\title{
Analysis of EDTA-soluble Cell Surface Components of Gram-positive Anaerobic Cocci
}

\author{
By Gillian L. F. SMITH, ${ }^{1}$ C. G. CUMMING ${ }^{2}$ and P. W. ROSS ${ }^{*}$ \\ 'Department of Bacteriology, University Medical School, Teviot Place, Edinburgh EH8 9AG, UK \\ ${ }^{2}$ Department of Oral Medicine and Oral Pathology, Old Surgeons Hall, High School Yards, \\ Edinburgh EHI INR, UK
}

(Received 16 September 1985 ; revised 5 February 1986)

The protein content of EDTA extracts from 76 strains of Gram-positive anaerobic cocci was examined using SDS-PAGE. Strains of Peptostreptococcus anaerobius produced almost identical profiles; greater heterogeneity was observed within the species Peptococcus magnus, Peptococcus prevotii and Peptococcus asaccharolyticus, but several strains within each biotype produced similar patterns. Serological investigation of these extracts by ELISA revealed numerous crossreactions among the different biotypes. Immunoblot transfers from polyacrylamide gels demonstrated two common antigens within strains of the species Ps. anaerobius, but these were not species-specific.

\section{INTRODUCTION}

Gram-positive anaerobic cocci (GPAC) belonging to the genera Peptococcus and Peptostreptococcus are frequently recovered from a variety of human infections. These include pulmonary and cerebral abscesses (Gorbach \& Bartlett, 1974; Ingham et al., 1977), and intra-abdominal (Gorbach \& Bartlett, 1974), female genital tract (Thadepalli et al., 1973) and orofacial infections (Busch, 1984). In most cases GPAC are present with other anaerobic and facultative organisms; therefore the precise contribution of GPAC to the overall disease process is obscure. A considerable hindrance to studies of the pathogenicity of GPAC is the absence of a practical identification scheme for diagnostic laboratories (Watt et al., 1984). Current schemes (Holdeman et al., 1977; Dowell \& Hawkins, 1974; Sutter et al., 1975) involve numerous biochemical tests and many species are defined on the basis of negative results. Polyacrylamide gel electrophoresis (PAGE) of cellular proteins has been utilized in studies of several microorganisms presenting taxonomic problems, for example mycoplasmas (Razim \& Rottem, 1967), corynebacteria (Jackman, 1982) and clostridia (Cato et al., 1982). Results obtained by this procedure have agreed with those from DNA-DNA homology studies. An alternative approach to the classification of micro-organisms is examination of their serological characteristics, including identification of cellular components which induce the formation of specific antibodies in laboratory animals. The detection of such antibodies in the sera of patients is of diagnostic and epidemiological importance.

The aims of the present study were to extract cell surface components from a variety of GPAC, and then to examine their protein profiles using SDS-PAGE and determine their antigenic content using the techniques of immunoblot transfer to nitrocellulose and ELISA.

\section{METHODS}

Bacteria. Seventy-six strains representing four species of GPAC (Peptostreptococcus anaerobius, Peptococcus magnus, Peptococcus prevotii and Peptococcus asaccharolyticus) were selected for study. These comprised one ATCC and five NCTC strains and 70 clinical isolates. All were obligate anaerobes as defined by Watt \& Jack

Abbreviations: GPAC, Gram-positive anaerobic cocci; CMB, Robertson's cooked meat broth; TBS, Trisbuffered saline; TTBS, Tween 20-TBS; HRP, horseradish peroxidase; HSA, human serum albumin. 
(1977) and were identified to species level according to VPI (Virginia Polytechnic Institute) criteria (Holdeman et al., 1977). Strains of GPAC were stored as lyophilized preparations or in $10 \%(\mathrm{w} / \mathrm{v})$ skimmed milk at $-20{ }^{\circ} \mathrm{C}$.

Culture and harvest of bacteria. Organisms were reconstituted with pre-reduced modified Robertson's cooked meat broth (CMB; Watt, 1972) and incubated anaerobically at $37^{\circ} \mathrm{C}$ for $48 \mathrm{~h}$, according to the method of Collee $e t$ al. (1972). CMB cultures were then used to inoculate $200 \mathrm{ml}$ pre-reduced CMB (Deacon et al., 1978). After anaerobic incubation for $48 \mathrm{~h}$ at $37^{\circ} \mathrm{C}$, cells were harvested by centrifugation $(20000 \mathrm{~g}, 10 \mathrm{~min})$ washed twice in $40 \mathrm{ml}$ phosphate-buffered saline (PBS: $50 \mathrm{~mm}$-phosphate buffer, $\mathrm{pH} \mathrm{7.5}$, with $0.15 \mathrm{~mm}-\mathrm{NaCl}$ ) and finally centrifuged as before.

EDTA extraction. Washed cells were resuspended in $2 \mathrm{ml}$ PBS containing $10 \mathrm{~mm}$-EDTA (pH 7.4) and transferred to a $45^{\circ} \mathrm{C}$ water bath for $60 \mathrm{~min}$. This suspension was centrifuged $(10000 \mathrm{~g}, 3 \mathrm{~min})$ and the supernatant, which contained the extract, was transferred to acid-washed Bijou bottles. The protein content of individual EDTA extracts was estimated by the Lowry method, using bovine serum albumin $\left(2 \mathrm{mg} \mathrm{ml}^{-1}\right)$ as a standard.

Antiserum preparation. Four clinical isolates of GPAC were selected for the production of antisera in rabbits, based on the method of Poxton (1979). The strains were Ps. anaerobius (GPAC 56393) from a case of otorrhoea, $P c$. magnus (GPAC 149) and Pc.prevotii (GPAC 150), both from wound infections, and Pc. asaccharolyticus (STD 34) from the vagina of a female attending a sexually-transmitted disease clinic. Two New Zealand White rabbits per strain were inoculated intravenously with $10^{9}$ bacteria in $1 \mathrm{ml}$ PBS on three consecutive days each week for four weeks. Antibody titres were determined from test bleeds using an ELISA procedure (see below). The majority of animals were exsanguinated in the fifth week; the pair inoculated with $P c$. prevotii received two further doses of $10^{10}$ and $10^{11}$ bacteria in weeks five and six before exsanguination.

$S D S-P A G E$. A modified version of the method of Laemmli (1970) was used, as described by Poxton \& Brown (1979). Vertical slab gels $(170 \times 140 \times 1 \mathrm{~mm})$ consisted of a $10 \mathrm{~mm}, 4 \%(w / v)$ acrylamide stacking gel above a $10 \%(\mathrm{w} / \mathrm{v})$ acrylamide separating gel. EDTA extracts containing $100 \mu \mathrm{g}$ protein, suspended in $100 \mu \mathrm{l}$ single strength sample buffer, were boiled for $3 \mathrm{~min}$, and then added to wells in the stacking gel: $60 \mathrm{~V}$ were applied to the gel to move samples through the stacking gel (1-2 h), followed by $150 \mathrm{~V}(2-3 \mathrm{~h})$ for separation. Gels were stained with Coomassie blue (Poxton \& Sutherland, 1976).

Immunoblot transfer. The technique described by Cousland \& Poxton (1983) was adopted. EDTA extracts adjusted to $10 \mu \mathrm{g}$ protein in $50 \mu \mathrm{l}$ sample buffer (boiled for $3 \mathrm{~min}$ ) were run in duplicate SDS-polyacrylamide gels as described, but electrophoresis was halted when the gel front had travelled $7.5 \mathrm{~cm}$ into the separating gel. One gel was stained with silver (Oakley et al., 1980) to demonstrate protein profiles. To detect antigens in EDTA extracts the duplicate gel was used in an immunoblot transfer procedure, with a BioRad Immunoblot assay kit, according to the method of Towbin et al. (1979). Material from the gel was transferred to a nitrocellulose membrane $(0 \cdot 2 \mu \mathrm{m}$ pores) by electrophoresis in Tris/glycine/methanol buffer ( $\mathrm{pH} 8.3)$ for $18 \mathrm{~h}$ at $12 \mathrm{~V}(40 \mathrm{~mA})$. After a $10 \mathrm{~min}$ wash in Tris-buffered saline (TBS : $20 \mathrm{~mm}$-Tris $/ \mathrm{HCl}, 500 \mathrm{mM}-\mathrm{NaCl}, \mathrm{pH} 7.5$ ) and blocking for $45 \mathrm{~min}$ in $3 \%$ (w/v) gelatinTBS, the nitrocellulose was placed in first antibody solution for $2.5 \mathrm{~h}$ (antisera to $P c$. magnus, Pc. prevotii and $P c$. asaccharolyticus were diluted $1: 50$ in $1 \%(\mathrm{w} / \mathrm{v})$ gelatin-TBS, whereas $P$ s. anaerobius antiserum was diluted $1: 250)$. Following two $10 \mathrm{~min}$ washes in 0.025\% (v/v) Tween 20-TBS (TTBS), the nitrocellulose was incubated for $1 \mathrm{~h}$ in second antibody solution containing goat anti-rabbit IgG-horseradish peroxidase (HRP) conjugate diluted $1: 3000$ in $1 \%(w / v)$ gelatin-TBS. The nitrocellulose was then washed as before and transferred to HRP colour development solution containing 4-chloro-1-naphthol and hydrogen peroxide. Development was stopped by immersing the nitrocellulose in distilled water after 15-30 min.

ELISA. The method used was essentially that of Engvall \& Perlmann (1972) adapted for microtitre plates. EDTA extracts were adjusted to $30 \mu \mathrm{g}$ protein $\mathrm{ml}^{-1}$ and results were read in a Titretek Multiskan (Organon Teknika, St Neots, UK). End-points of titrations were taken as the first dilution of antisera to give an $A_{405}$ value of 1.0 .

Treatment of EDTA-extracted antigens. An EDTA extract from Ps. anaerobius (GPAC 56393) was adjusted to $200 \mu \mathrm{g}$ protein $\mathrm{ml}^{-1}$ and subjected to the following treatments, as described by Poxton \& Byrne (1981). (i) Heat treatment $\left(121{ }^{\circ} \mathrm{C}\right.$ for $15 \mathrm{~min}$ ). (ii) Formalin (as $20 \%$, w/v, formaldehyde) for $16 \mathrm{~h}$ at $20^{\circ} \mathrm{C}$, followed by dialysis for $18 \mathrm{~h}$ at $4{ }^{\circ} \mathrm{C}$ against PBS. This treatment denatures proteins. (iii) Sodium periodate $(0 \cdot 1 \mathrm{M})$ for $16 \mathrm{~h}$ at $20^{\circ} \mathrm{C}$ in the dark; excess periodate was removed with ethylene glycol; this was followed by dialysis for $18 \mathrm{~h}$ at $4{ }^{\circ} \mathrm{C}$ against PBS. This treatment oxidizes carbohydrates.

Two controls were included : an untreated EDTA extract and, as the periodate control, an EDTA extract treated as described in (iii) above, but with distilled water instead of periodate. Control and treated extracts $(75 \mu \mathrm{l})$ were mixed with equal volumes of sample buffer containing SDS, boiled for $3 \mathrm{~min}$ and run in duplicate polyacrylamide gels $(10 \mu \mathrm{g}$ protein per track). One gel was stained with silver for proteins; the other was used in an immunoblot transfer to nitrocellulose. Incubation of the latter with antiserum to GPAC 56393 revealed denaturation of antigens associated with each treatment, relative to untreated controls, which gave an indication of their chemical nature. 


\section{RESULTS \\ Antibody titres}

Sera from each pair of rabbits were pooled and antibody titres determined by ELISA, using EDTA extracts as antigens, with the following results: Ps. anaerobius $1: 8000 ; P c$. asaccharolyticus and Pc. magnus 1:1600; Pc. prevotii 1:200. Despite two booster injections, $P c$. prevotii proved to be poorly immunogenic relative to the other strains.

\section{$S D S-P A G E$}

The protein profiles of five strains each of $P$ s. anaerobius and $P c$. magnus stained with Coomassie blue are shown in Fig. 1. Striking similarities are apparent between strains of $P s$. anaerobius (tracks 2-6), and the patterns are dominated by a single darkly-staining band corresponding in mobility to ovotransferrin $\left(M_{\mathrm{r}} 76000-78000\right.$; track 1$)$; other regions in the patterns show qualitative and quantitative variations. These features were observed in all strains of Ps. anaerobius tested. The profiles of Pc. magnus (tracks 7-11) show greater heterogeneity, particularly track 10 which contains an extract from NCTC 9815.

Strains of Pc. prevotii also exhibited heterogeneous protein profiles (Fig. 2), but patterns in tracks 4 and 5 are very similar, and tracks 8 and 9 have many bands in common. Despite receiving the same amount of protein, bands in track 7 stained very faintly. Similar features were displayed by strains of $P$ c. asaccharolyticus (not shown), i.e. overall heterogeneity, but with several well-defined bands common to all extracts. Only $P$ s. anaerobius produced protein profiles which were visually almost identical. The observation of groups of strains with almost identical protein profiles within species suggested a potential method for classifying GPAC.

\section{Immunoblot transfer}

This technique was chosen to investigate the antigenic content of EDTA extracts from GPAC. Nitrocellulose membranes were probed with antisera homologous to the species run in the corresponding polyacrylamide gels. In the case of Ps. anaerobius, the high $M_{\mathrm{r}}$ band seen in earlier gels proved to be an antigen common to the 13 strains investigated, including ATCC 27337 . A second common antigen of lower $M_{\mathrm{r}}$ (approximately equivalent to myoglobin, $M_{\mathrm{r}} 17200$, in mobility) was also demonstrated. Some strains of $P s$. anaerobius possessed antigens not shared with other isolates of this species (results not shown).

Similar procedures with EDTA extracts from seven strains each of $P c$. prevotii, Pc. magnus and $P c$. asaccharolyticus highlighted the following features: many strains within each species possessed common antigens and a small number of strains (two strains of $P c$. magnus and one strain each of $P$ c. prevotii and $P c$. asaccharolyticus) displayed additional unshared antigens; one strain of $P c$. prevotii, three strains of $P c$. magnus and one strain of $P c$. asaccharolyticus did not react with homologous antisera which suggested misidentification of these strains or the vaccine strain by conventional means.

\section{Cross-reactivity between GPAC}

To determine the presence of cross-reacting antigens, EDTA extracts from 50 strains of GPAC were tested in an ELISA procedure against each of the four antisera. A single dilution of each antiserum was used as follows: Ps. anaerobius $1: 1000 ; P c$. magnus and $P c$. asaccharolyticus $1: 500 ;$ Pc. prevotii $1: 100$. An $A_{405}$ value of $\geqslant 1.0$ indicated a significant positive reaction, but a value of 0.8 was included as a 'borderline' reaction. All 15 strains of Ps. anaerobius reacted strongly with the homologous antiserum; six strains also reacted with $P c$. magnus antiserum and three of these also reacted with Pc. prevotii antiserum. Only six strains of Pc. magnus reacted strongly with the homologous antiserum and one of these was borderline; cross-reactions were observed between Pc. magnus and antisera to Pc.prevotii, Ps. anaerobius and Pc. asaccharolyticus. One strain of $P$ c. asaccharolyticus cross-reacted with antisera to $P$ s. anaerobius and $P c$. magnus; a further strain reacted with antiserum to $P c$. prevotii. Of the strains of $P c$. prevotii tested only an extract from the vaccine strain (GPAC 150) reacted strongly with its antiserum. Two strains biotyped as Pc. prevotii were serologically identified as Pc. magnus and Ps. asaccharolyticus respectively, but the latter also had antigens in common with Ps. anaerobius. 


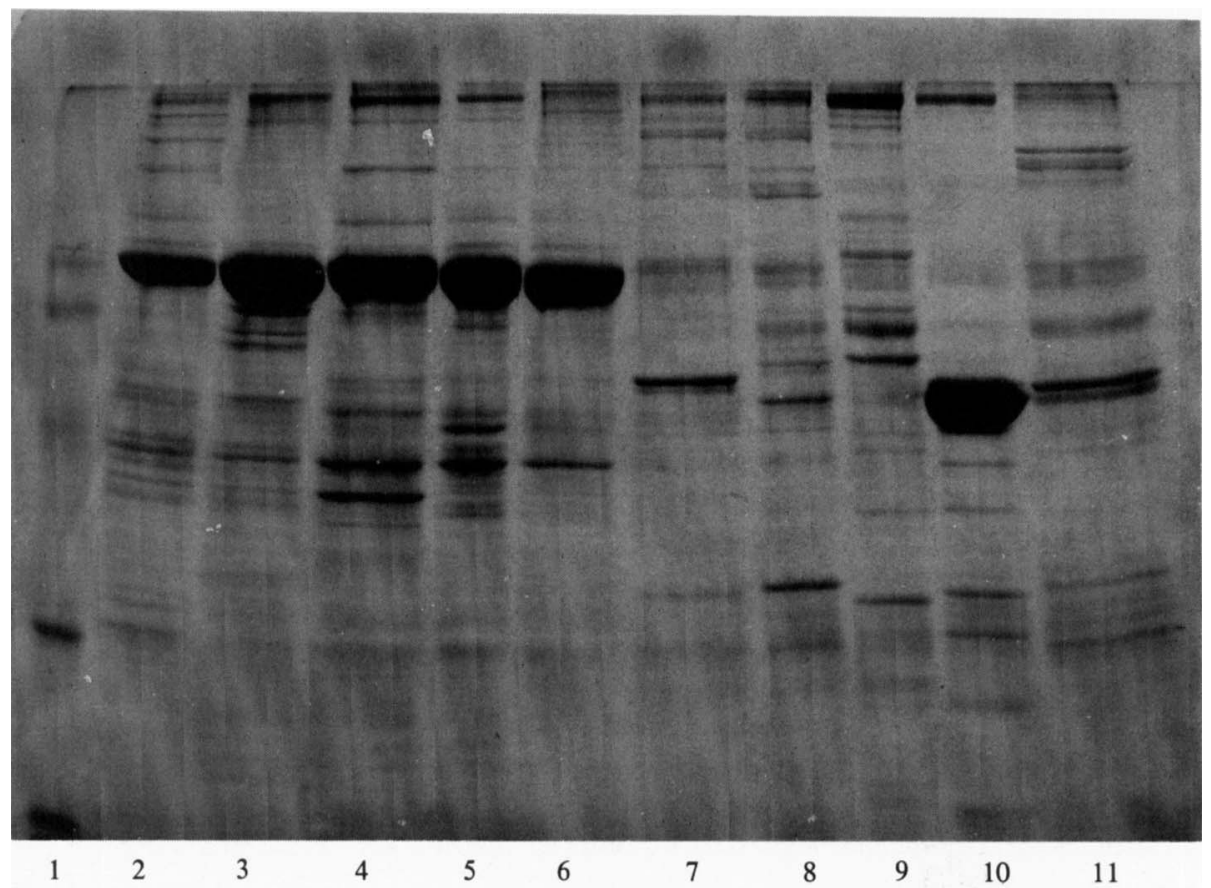

Fig. 1. PAGE of EDTA extracts from five strains of $P$ s. anaerobius (tracks 2-6) and five strains of $P c$. magnus (tracks 7-11). Track 1 contains the following $M_{r}$ marker proteins (BDH) in order from the top of the gel downwards: ovotransferrin $\left(M_{\mathrm{r}} 76-78000\right)$; albumin (66250); ovalbumin (45000); chymotrypsinogen A (25700); myoglobin (17200); cytochrome $c(12300)$. The gel was stained with Coomassie blue.

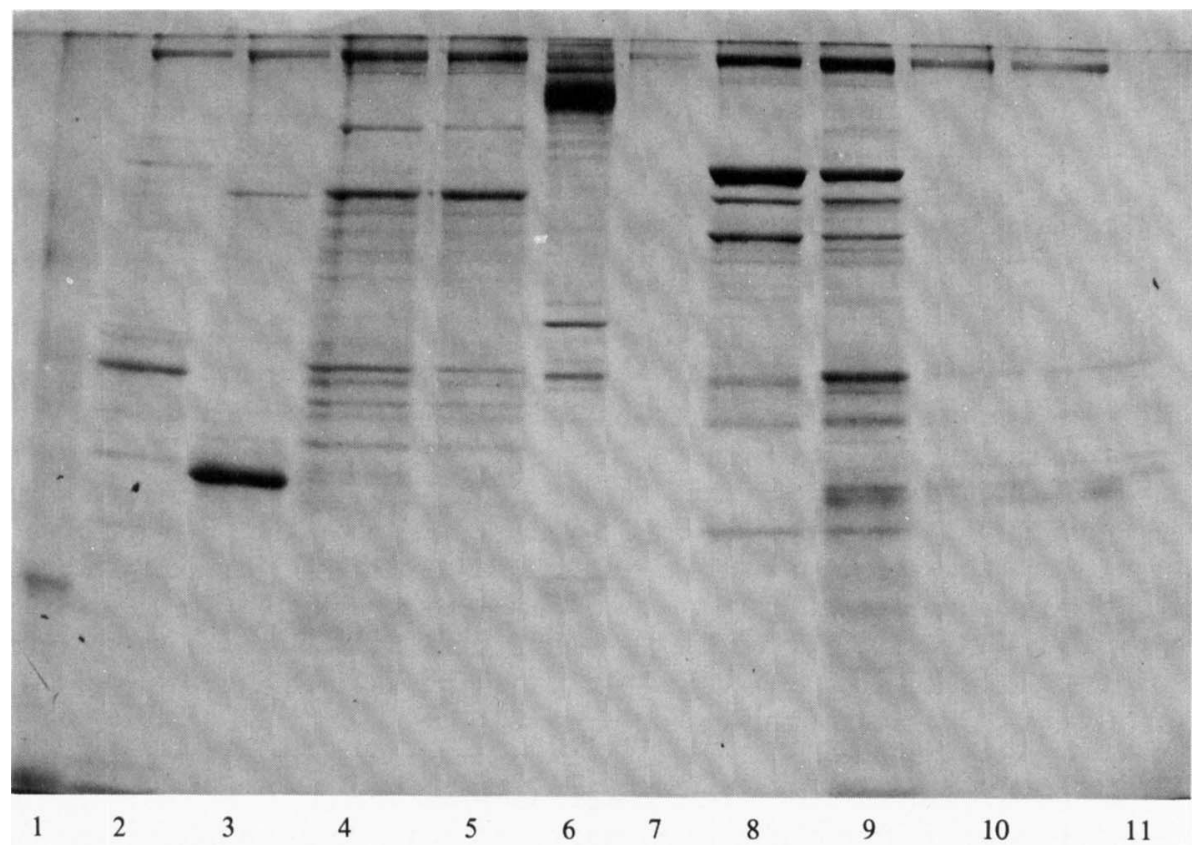

Fig. 2. PAGE of EDTA extracts from 10 strains of $P c$. prevotii (tracks 2-11). Track 1 contains $M_{\mathrm{r}}$ markers (see Fig. 1). The gel was stained with Coomassie blue. 


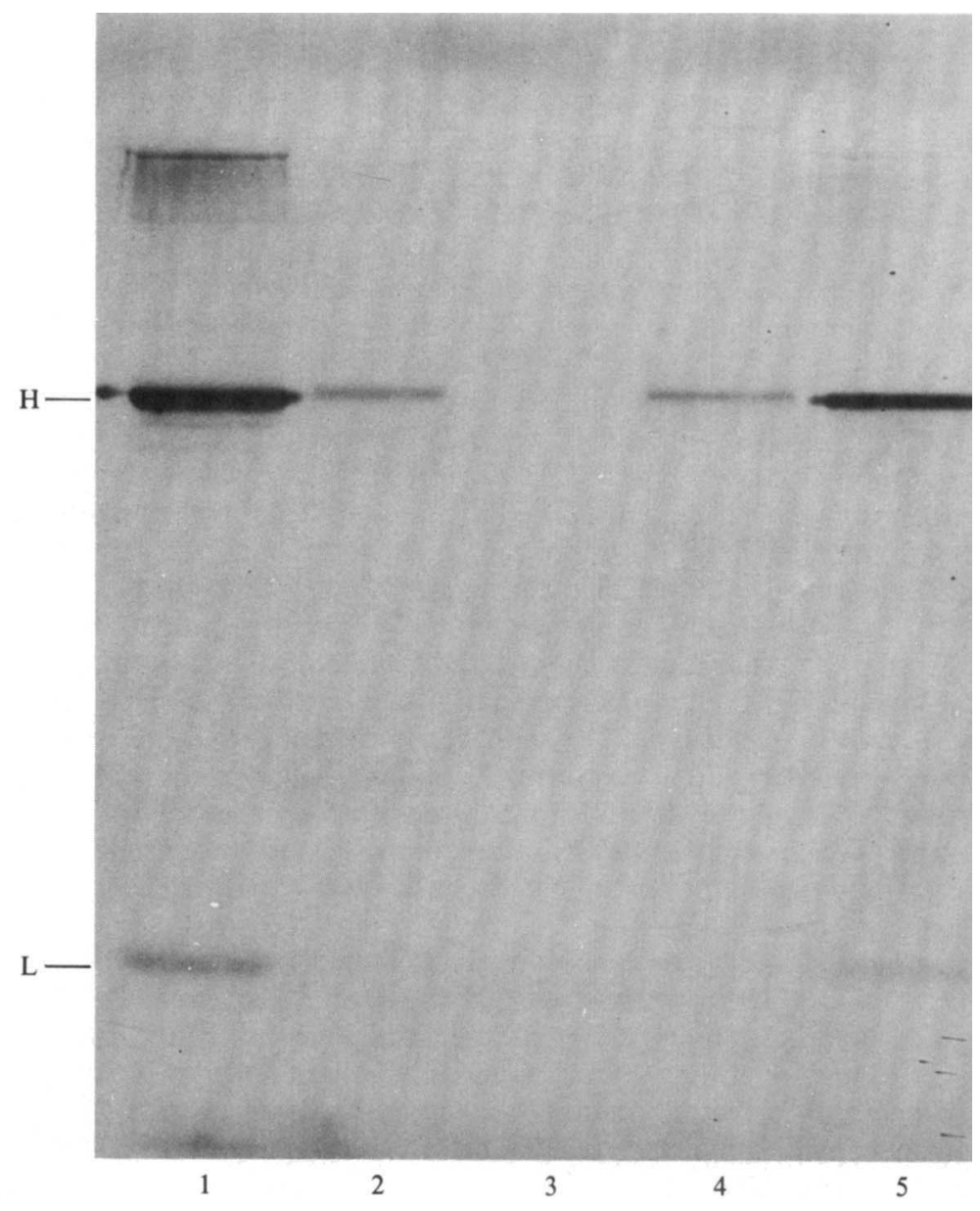

Fig. 3. Immunoblot transfer from a polyacrylamide gel of control and treated EDTA extracts from $P s$. anaerobius. Track 1, untreated control with high $(\mathrm{H})$ and low $(\mathrm{L}) M_{\mathrm{r}}$ antigens common to this species; track 2, heat-treated extract; track 3, formalin-treated extract; track 4, periodate-treated extract; track 5 , periodate control.

Treatment of EDTA-extracted antigens of Ps. anaerobius

The use of PAGE and immunoblot transfer to visualize the effects of various treatments on the two common antigens contained in an EDTA extract from Ps. anaerobius is illustrated in Fig. 3: track 1 contains the untreated extract and demonstrates the high and low $M_{\mathrm{r}}$ antigens common to all strains of Ps. anaerobius examined by this procedure; track 2 contains the heattreated extract from which the low $M_{\mathrm{r}}$ antigen has disappeared; track 3 contains the formalintreated extract from which both antigens have disappeared; track 4 contains the periodatetreated extract which lacks the low $M_{\mathrm{r}}$ antigen, similar to track 2 ; track 5 contains the periodate control, in which both antigens are still present. The reactions of the high $M_{\mathrm{r}}$ antigen after heat and periodate treatments (tracks 2 and 4) are reduced in intensity; this suggests some degree of denaturation, since all tracks received the same amount of protein.

\section{DISCUSSION}

In the present study, the protein content of EDTA extracts from a variety of GPAC was studied using SDS-PAGE. Incubation of Gram-positive cells with EDTA causes the solubilization of non-covalently bound cell surface polymers, including proteins and membrane- 
associated lipocarbohydrates (Poxton \& Byrne, 1981). This treatment, however, does not break covalent bonds; therefore secondary wall polymers (teichoic acids or their analogues) are not removed. Autolysis of GPAC cells was not observed during the $60 \mathrm{~min}$ incubation period.

The method of immunizing rabbits used produced antibody titres that compared favourably with previous reports (Stone, 1940; Markowitz \& Lerner, 1977); the titre obtained for Ps. anaerobius confirms the report of Wong et al. (1980) that this species is strongly immunogenic. The technique of SDS-PAGE has been successfully used in taxonomic studies of several groups of micro-organisms. Cato et al. (1983) observed a 'general similarity' in the patterns of whole cell proteins extracted from strains of $P$ c. magnus, but greater variation within the species $P$ s. micros. In the present study, EDTA extracts from Pc. magnus, $P c$. prevotii and Pc. asaccharolyticus produced heterogeneous profiles in gels stained with Coomassie blue that were not characteristic of their biotype. Within these species, however, a number of strains produced very similar patterns, suggesting that many GPAC could be assigned to distinct groups by this technique. Strains of Ps. anaerobius consistently produced almost identical protein patterns dominated by one high $M_{\mathrm{r}}$ band. Immunoblots of 13 strains revealed that this band and another of low $M_{\mathrm{r}}$ were antigens common to this species, which confirms previous reports (Wong et al., 1980; Graham \& Falkler, 1979). The high $M_{\mathrm{r}}$ antigen was denatured by formalin, but not by heat or periodate, which suggests that its determinant sites contain protein. Heat, periodate and formalin denatured the low $M_{\mathrm{r}}$ antigen, suggesting that it contains both carbohydrate and protein moieties. Sensitivity to proteolytic enzymes, but resistance to heat and periodate, are characteristics of a receptor for human serum albumin (HSA) on the surface of Pc. magnus recently described by Myhre (1984); however, no indication of its $M_{\mathrm{r}}$ was given. Serological cross-reactions between $P$ c. magnus and $P$ s. anaerobius were observed in this study and it would be of interest to determine whether or not these involve a molecule on the surface of $P s$. anaerobius capable of binding HSA.

Numerous serological cross-reactions between different biotypes of GPAC were demonstrated by ELISA, indicating the presence of shared antigens. For three of the 50 strains tested, ELISA suggested identities contrary to those deduced from biochemical tests; a total of 19 strains could not be identified with the antisera used. Graham \& Falkler (1979) and Wong et al. (1980) produced evidence that the antigens common to strains of Ps. anaerobius were not possessed by other peptostreptococci. The present study involves different antigen and antiserum preparations; therefore although results are not directly comparable, they indicate that the antigens contained in EDTA extracts of $P$ s. anaerobius are not unique to this species because these antigens were also detected by antisera to $P c$. magnus and $P c$. prevotii. In addition, antiserum to $P$ s. anaerobius recognized antigens in extracts from $P c$. magnus and $P c$. asaccharolyticus.

This study has shown that GPAC identified to species level by conventional biochemical tests possess a range of cell surface antigens, some of which are not species-specific. Extracts containing these antigens were easily prepared from GPAC, and the technique of immunoblotting offered a simple and sensitive means for their detection. We suggest that further investigation of the serological characteristics of such extracts following SDS-PAGE may aid the classification of GPAC.

\section{REFERENCES}

Busch, D. F. (1984). Anaerobes in infections of the head and neck and ear, nose and throat. Review of Infectious Diseases 6, Supplement 1, 115-122.

Cato, E. P., Hash, D. E., Holdeman, L. V. \& Moore, W. E. C. (1982). Electrophoretic study of Clostridium species. Journal of Clinical Microbiology 15, 688-702.

Cato, E. P., Johnson, J. L., Hash, D. E. \& Holdeman, L. V. (1983). Synonymy of Peptococcus glycinophilus (Cardon and Barker 1946) Douglas 1957 with Peptostreptococcus micros (Prevot 1933) Smith 1957 and electrophoretic differentiation of Peptostreptococcus micros from Peptococcus magnus (Prevot 1933)
Holdeman and Moore 1972. International Journal of Systematic Bacteriology 33, 207-210.

Collee, J. G., Watt, B., Fowler, E. B. \& Brown, R. (1972). An evaluation of the Gaspak system in the culture of anaerobic bacteria. Journal of Applied Bacteriology 35, 71-82.

Cousland, G. \& Poxton, I. R. (1983). Analysis of lipopolysaccharides of Bacteroides fragilis by sodium dodecyl sulphate-polyacrylamide gel electrophoresis and electroblot transfer. FEMS Microbiology Letters 20, 461-465.

Deacon, A. G., Duerden, B. I. \& Holbrook, W. P. 
(1978). Gas-liquid chromatographic analysis of metabolic products in the identification of Bacteroidaceae of clinical interest. Journal of Medical Microbiology 11, 8I-89.

Dowell, V. R. \& Hawkins, T. M. (1974). Laboratory methods in bacteriology. CDC Laboratory Manual. Department of Health Education and Welfare publication no. (CDC) 74-8272.

Engvall, E. \& Perlmann, P. (1972). Enzyme-linked immunosorbent assay, ELISA. III. Quantitation of specific antibodies by enzyme-labelled anti-immunoglobulin in antigen-coated tubes. Journal of Immuno$\log y 109,129-135$.

Gorbach, S. L. \& Bartlett, J. G. (1974). Anaerobic infections. New England Journal of Medicine 290, $1177-1184,1237-1245,1289-1294$.

GRAHAM, M. B. \& FALKLER, W. A. (1979). Extractableantigen shared by Peptostreptococcus anaerobius strains. Journal of Clinical Microbiology 9, 507-510.

Holdeman, L. V., Cato, E. P. \& Moore, W. E. C. (1977). Anaerobe Laboratory Manual, 4th edn. Blacksburg, Virginia: Virginia Polytechnic Institute and State University.

INGhaM, H. R., Selkon, J. B. \& Roxby, C. M. (1977). Bacteriological study of otogenic cerebral abscesses: chemotherapeutic role of metronidazole. British Medical Journal 2, 991-993.

JACKMAN, P. J. H. (1982). Classification of Corynebacterium species from axillary skin by numerical analysis of electrophoretic protein patterns. Journal of Medical Microbiology 15, 485-492.

LAEMMLI, U. K. (1970). Cleavage of structural proteins during the assembly of the head of bacteriophage T4. Nature, London 227, 680-685.

MARKowitz, A. \& Lerner, A. M. (1977). Differentiation of several isolates of Peptococcus magnus by counter-immunoelectrophoresis. Infection and Immunity 16, 152-154.

MYHRE, E. B. (1984). Surface receptors for human serum albumin in Peptococcus magnus strains. Journal of Medical Microbiology 18, 189-195.

OAKLEY, B. R., KIRSCH, D. R. \& MORRIS, N. R. (1980). A simplified ultra-sensitive silver stain for detecting proteins in polyacrylamide gels. Analytical Biochemistry 105, 361-363.

PoxTON, I. R. (1979). Serological identification of Bacteroides species by an enzyme-linked immunosorbent assay. Journal of Clinical Pathology 32, 294-298.
Poxton, I. R. \& Brown, R. (1979). Sodium dodecy] sulphate-polyacrylamide gel electrophoresis of cellsurface proteins as an aid to identification of the Bacteroides fragilis group. Journal of General Microbiology 112, 211-217.

Poxton, I. R. \& Byrne, M. D. (1981). Immunological analysis of the EDTA-soluble antigens of Clostridium difficile and related species. Journal of General Microbiolog! 122, 41-46.

Poxton, I. R. \& Sutherland I. W. (1976). The butanol-soluble proteins of Klebsiella aerogenes. Microbios 15, 93-103.

RaziM, S. \& RotTEM, S. (1967). Identification of Mycoplasma and other microorganisms by polyacrylamide gel electrophoresis of cell proteins. Journal of Bacteriology 94, 1807-1810.

STONE, M. L. (1940). Studies on the anaerobic streptococcus. I. Certain biochemical and immunological properties of anaerobic streptococci. Journal of Bacteriology 39, 559-582.

SutTer, V. L., VARGo, V. L. \& Finegold, S. M. (1975). Wadsworth Anaerobic Bacteriology Manual, 2nd edn. Wadsworth Hospital Center, Nev., USA: Anaerobic Bacteriology Laboratory.

Thadepalli, H., Gorbach, S. L. \& KeITh, L. (1973). Anaerobic infections of the female genital tract: bacteriologic and therapeutic aspects. American Journal of Obstetrics and G.necolog. 117, 1034-1040.

Towbin, H., Staemelin, T. \& GoRdon, J. (1979). Electrophoretic transfer of proteins from polyacrylamide gels to nitrocellulose sheets: procedure and some applications. Proceedings of the National Academy of Sciences of the United States of America 76, 4350-4354.

WATT, B. (1972). The recovery of clinically important anaerobes on solid media. Journal of Medical Microbiology 5, 211-218.

WATT, B. \& JACK, E. P. (1977). What are anaerobic cocci? Journal of Medical Microbiology 10, 461-468.

Watt, B., Bushell, A. C. \& Wallace, E. T. (1984). Characterisation of anaerobic cocci in the diagnostic laboratory. Journal of Clinical Pathology 37, 1197.

Wong, M., Catena, A. \& Hadley, W. K. (1980). Antigenic relationships and rapid identification of Peptostreptococcus species. Journal of Clinical Microbiology 11, 515-521. 